\section{REGULASI PELAKSANAAN REHABILITASI LINGKUNGAN KASUS PULAU BANGKA ${ }^{1}$ \\ Oleh : Garth Imanuel Koleangan ${ }^{2}$ \\ Flora Pricillia Kalalo ${ }^{3}$ \\ Fernando J. M. M Karisoh ${ }^{4}$}

\begin{abstract}
ABSTRAK
Tujuan dilakukannya penelitian ini adalah untuk mengetahui bagaimana eksekusi Putusan Peradilan Tata Usaha Negara terkait kasus Pulau Bangka dan bagaimana pertanggungjawaban untuk melakukan rehabilitasi terhadap kerusakan lingkungan di Pulau Bangka. Dengan menggunakan metode penelitian yuridis normatif, disimpulkan: 1. Putusan Mahkamah Agung Nomor 291 K/TUN/2013 jo Putusan Pengadilan Tinggi Tata Usaha Negara Makassar Nomor 165/B.TUN/2012/PT.TUN.MKS jo Putusan Pengadilan Tata Usaha Negara Manado Nomor 04/G.TUN/2012/PTUN.MDO yang telah
\end{abstract} mempunyai kekuatan hukum tetap, memerintahkan Kepada Bupati Minahasa Utara untuk mencabut Surat Keputusan Bupati Minahasa Utara Nomor 162 Tahun 2010 tanggal 20 Juli 2010 tentang Perpanjangan dan Perluasan Kuasa Pertambangan Ekplorasi Serta Penyesuaian Menjadi Izin Usaha Pertambangan (IUP) Eksplorasi Kepada PT Mikgro Metal Perdana di Pulau Bangka, Kecamatan Likupang Timur, Kabupaten Minahasa Utara dan Surat Keputusan Bupati Minahasa Utara Nomor 152 Tahun 2012 tanggal 20 Juli 2012 tentang Perpanjangan Izin Usaha Pertambangan (IUP) Eksplorasi Kepada PT Mikgro Metal Perdana di Pulau Bangka, Kecamatan Likupang Timur, Kabupaten Minahasa Utara, hingga saat ini eksekusi terhadap putusan tersebut belum dilakukan. Mekanisme untuk mengusahakan dipatuhinya putusan oleh Bupati Minahasa Utara telah dilakukan oleh PTUN Manado, namun tetap tidak membuahkan hasil. 2. Dengan dikeluarkannya Surat Keputusan Menteri Energi dan Sumber Daya Mineral Republik Indonesia Nomor 1361 K/30/MEM/2017 tentang Pencabutan Keputusan Menteri Energi dan Sumber Daya

\footnotetext{
${ }^{1}$ Artikel Skripsi

${ }^{2}$ Mahasiswa pada Fakultas Hukum Unsrat, NIM : 16071101029

${ }^{3}$ Fakultas Hukum Unsrat, Doktor IImu Hukum

${ }^{4}$ Fakultas Hukum Unsrat, Magister IImu Hukum
}

Mineral Nomor 3109 K/30/MEM/2014 tanggal 17 Juli 2014 tentang Izin Usaha Pertambangan Operasi Produksi Kepada PT Mikgro Metal Perdana, menghentikan seluruh kegiatan pertambangan PT Mikgro Metal Perdana di Pulau Bangka. Sebagai pemegang Izin Usaha Pertambangan, PT Mikgro Metal Perdana diwajibkan untuk melakukan rehabilitasi/reklamasi pascatambang untuk mengembalikan fungsi lingkungan Pulau Bangka sesuai ketentuan peraturan perundangundangan nasional.

Kata kunci: Regulasi, Rehabilitasi, Lingkungan. Kasus Pulau Bangka.

\section{PENDAHULUAN}

\section{A. Latar Belakang}

Penulis mengambil studi terhadap Putusan Pengadilan Tata Usaha Negara Manado Nomor: 64/G/TUN/2012/PTUN/Mdo tanggal 30 Agustus 2012, Jo. Putusan Pengadilan Tinggi Tata Usaha Negara Makassar Nomor: 165/B/2012/PT.TUN.Mks tanggal 01 Maret 2013, Jo. Putusan Kasasi Mahkamah Agung Nomor: $291 \mathrm{~K} / \mathrm{TUN} / 2013$ tanggal 24 september 2013, Jo. Putusan Peninjauan Kembali Nomor: 127 PK/TUN/2014 tanggal 04 Maret 2014 yang pada intinya memerintahkan Bupati Minahasa Utara untuk membatalkan Surat Keputusan Bupati Minahasa Utara Nomor 162 Tahun 2010 tanggal 20 Juli 2010 tentang Perpanjangan dan Perluasan Kuasa Pertambangan Ekplorasi Serta Penyesuaian Menjadi Izin Usaha Pertambangan (IUP) Eksplorasi Kepada PT Mikgro Metal Perdana di Pulau Bangka, Kecamatan Likupang Timur, Kabupaten Minahasa Utara dan Surat Keputusan Bupati Minahasa Utara Nomor 152 Tahun 2012 tanggal 20 Juli 2012 tentang Perpanjangan Izin Usaha Pertambangan (IUP) Eksplorasi Kepada PT Mikgro Metal Perdana di Pulau Bangka, Kecamatan Likupang Timur, Kabupaten Minahasa Utara.

Keputusan Bupati Minahasa Utara tersebut memberikan izin melakukan kegiatan pertambangan kepada PT Mikgro Metal Perdana dengan luas wilayah mencakup setengah dari Pulau Bangka. Masyarakat Pulau Bangka merasa sangat dirugikan dengan Keputusan Bupati Minahasa Utara tersebut karena dikeluarkan tanpa sebelumnya disosialisasikan terlebih dahulu bersama masyarakat. Masyarakat pun merasa dirugikan 
dengan adanya kegiatan pertambangan di Pulau Bangka, karena dikhawaitrkan akan merusak lingkungan sekitar Pulau Bangka dan sehingga menurunnya sumber pendapatan warga yang sebagian besar adalah nelayan dan penurunan pendapatan dari pariwisata. Keputusan itu pun dianggap cacat formil dan tidak sesuai dengan peraturan perundanganundangan yang berlaku sehingga harus dinyatakan batal dan dicabut oleh Bupati Minahasa Utara.

Namun Bupati Minahasa Utara enggan menaati putusan pengadilan tersebut, dan terkesan membiarkan dan malah tetap mendukung kegiatan pertambangan di Pulau Bangka tetap terlaksana. Hal ini akhirnya menimbulkan protes berupa demo-demo yang dilakukan oleh masyarakat Pulau Bangka namun berujung pada tertangkapnya masyarakat oleh pihak keamanan yang merupakan anggota kepolisian dan anggota TNI AD.

Menteri ESDM Ignasius Jonan, kemudian mengeluarkan surat Keputusan untuk mencabut Izin Usaha Pertambangan (IUP) PT Mikgro Metal Perdana di Pulau Bangka. Pencabutan Izin Usaha Pertambangan (IUP) tersebut dituangkan dalam surat Keputusan Menteri Energi dan Sumber Daya Mineral Republik Indonesia Nomor 1361 K/30/MEM/2017 tentang Pencabutan Keputusan Menteri Energi dan Sumber Daya Mineral Nomor 3109 K/30/MEM/2014 tanggal 17 Juli 2014 tentang Izin Usaha Pertambangan Operasi Produksi Kepada PT Mikgro Metal Perdana.

Setelah melewati perjalanan yang cukup panjang, perjuangan masyarakat Pulau Bangka Kecamatan Likupang Timur, Kabupaten Minahasa Utara yang menolak keberadaan tambang biji besi PT Mikgro Metal Perdana akhirnya membuahkan hasil setelah Menteri ESDM, Ignasius Jonan, mencabut Izin Usaha Pertambangan (IUP) tersebut. Pencabutan Izin Usaha Pertambangan (IUP) tersebut dituangkan dalam surat Keputusan Menteri Energi dan Sumber Daya Mineral Republik Indonesia Nomor 1361 K/30/MEM/2017 tentang Pencabutan Keputusan Menteri Energi dan Sumber Daya Mineral Nomor 3109 K/30/MEM/2014 tanggal 17 Juli 2014 tentang Izin Usaha Pertambangan Operasi Produksi
Kepada PT Mikgro Metal Perdana. Namun bukan berarti masalah yang ada di Pulau Bangka telah selesai. Banyak pekerjaan rumah yang harus dihadapi terutama pemulihan atau rehabilitasi terhadap lingkungan sekitar Pulau Bangka yang akibat dari adanya kegiatan pertambangan menjadi rusak

Berdasarkan latar belakang tersebut maka penulis terdorong untuk membahas topik "Regulasi Pelaksanaan Rehabilitasi Lingkungan Dalam Kasus Pulau Bangka" dalam bentuk tulisan skripsi ini.

\section{B. Rumusan Masalah}

1. Bagaimana eksekusi Putusan Peradilan Tata Usaha Negara terkait kasus Pulau Bangka?

2. Bagaimana pertanggungjawaban untuk melakukan rehabilitasi terhadap kerusakan lingkungan di Pulau Bangka?

\section{Metode Penelitian}

Metode penelitian yang digunakan dalam penelitian ini adalah metode penelitian Yuridis Normatif. Menurut H. Ishaq mendefinisikan penelitian hukum normatif pada hakikatnya mengkaji hukum yang dikonsepkan sebagai norma atau kaidah yang berlaku dalam masyarakat dan menjadi acuan perilaku setiap orang. ${ }^{5}$

\section{PEMBAHASAN}

\section{A. Eksekusi Putusan Peradilan Tata Usaha Negara Terhadap Eksplorasi Pertambangan di Pulau Bangka}

Eksekusi dapat diartikan sebagai suatu tindakan lanjut dalam pelaksanaan suatu putusan pengadilan yang telah mempunyai kekuatan hukum yang tetap (incracht). Menurut R. Subekti, eksekusi atau pelaksanaan putusan mengandung arti bahwa pihak yang dikalahkan tidak mau menaati putusan itu secara sukarela sehingga putusan itu harus dipaksakan kepadanya dengan bantuan kekuatan umum. Sementara menurut Retno Wulan Sutantio dan Iskandar Oeripkartawinata menyatakan bahwa eksekusi adalah tindakan paksa oleh pengadilan terhadap pihak yang

\footnotetext{
${ }^{5} \mathrm{H}$. Ishaq. 2017. Metode Penelitian Hukum \& Penulisan
} Skripsi, Tesis dan Disertasi. Alfabeta. Bandung. HIm. 66. 
kalah dan tidak mau melaksanakan putusan secara sukarela. ${ }^{6}$

Dalam hukum acara PTUN ada macammacam bentuk eksekusi yang tercantum dalam ketentuan undang-undang. Antara lain:

1. Eksekusi otomatis

Eksekusi ini tercantum dalam ketentuan Pasal 116 ayat (1) dan (2) Undang-Undang Nomor 5 Tahun 1986. Dalam ketentuan ayat (2) menyatakan bahwa apabila dalam waktu 4 (empat) bulan setelah putusan berkekuatan hukum tetap dikirimkan dan tergugat tidak melaksanakan pencabutan objek sengketa maka keputusan TUN tersebut tidak mempunyai kekuatan hukum lagi. Dalam ketentuan Pasal 51 Undang-Undang No 51 Tahun 2009, ketentuan waktu "4 (empat bulan) setelah putusan berkekuatan hukum tetap dikirimkan" diubah menjadi waktu 60 hari kerja diterima (saat putusan diterima). Dalam pedoman teknis administrasi Peradilan Tata Usaha Negara melalui Ketua Pengadilan perlu membuat surat yang menyatakan Keputusan TUN yang dinyatakan batal atau tidak sah oleh putusan pengadilan yang telah berkekuatan hukum tetap tidak lagi mempunyai kekuatan hukum.

\section{Eksekusi hierarkis}

Eksekusi hierarkis diatur dalam ketentuan Pasal 116 ayat (6) Undang-Undang Nomor 51 Tahun 2009. Ketua pengadilan diharuskan untuk mengajukan hal ketidaktaatan pejabat tergugat atau termohon eksekusi kepada Presiden sebagai pemegang tertinggi dari kekuasaan pemerintahan untuk memerintahkan pejabat tersebut melaksanakan putusan pengadilan. $\mathrm{Di}$ samping itu juga mengajukannya kepada lembaga perwakilan rakyat untuk menjalankan fungsi pengawasan.

3. Eksekusi upaya paksa

Ditentukan pada ayat (3) Pasal 116 UndangUndang Nomor 9 Tahun 2004 bahwa dalam hal tergugat ditetapkan harus melaksanakan kewajibannya mencabut Keputusan Tata Usaha Negara (KTUN) atau menerbitkan KTUN yang baru atau menerbitkan KTUN dalam hal objek gugatan fiktif negative dan kemudian setelah 3 (tiga) bulan sejak putusan disampaikan kepada pihak tergugat (menurut Undang-Undang

\footnotetext{
6 https://raypratama.blogspot.com/2015/04/eksekusiputusan-pengadilan-tata-usaha.html? $\mathrm{m}=1$ diakses tanggal 31 agustus 2020 Pukul 21.25 WITA.
}

Nomor 51 Tahun 2009, 90 hari kerja sejak diterima) dan ternyata kewajiban tersebut tidak dilaksanakan, penggugat mengajukan permohonan kepada ketua pengadilan yang mengadili pada tingkat pertama agar memerintahkan tergugat melaksanakan putusan pengadilan tersebut.

Setelah ketua pengadilan memerintahkan untuk melaksanakan putusan (Pasal 116 ayat (4) dan (5) Undang-Undang Nomor 9 Tahun 2004 dan Undang-Undang Nomor 51 Tahun 2009) ternyata tergugat tidak bersedia melaksanakannya, maka terhadap pejabat yang bersangkutan dikenakan upaya paksa berupa "pembayaran sejumlah uang paksa/dwangsom" dan/atau "sanksi administratif" dan pejabat yang tidak melaksanakan putusan pengadilan sebagaimana dimaksud "diumumkan pada media massa cetak setempat oleh Panitera sejak tidak terpenuhinya ketentuan tersebut".

Ketidaktaatan tergugat atas putusan peradilan tata usaha negara terjadi juga dalam kasus Pulau Bangka. Bupati Minahasa Utara seakan enggan untuk menaati Putusan Kasasi Mahkamah Agung Nomor 291 K/TUN/2013 jo Putusan Banding PTTUN Makassar Nomor 165/B.TUN/2012/PT.TUN.MKS jo. Putusan PTUN Manado Nomor 4/G.TUN/2012/PTUN.MDO untuk mencabut Surat Keputusan Bupati Minahasa Utara Nomor 162 Tahun 2010 tanggal 20 Juli 2010 tentang Perpanjangan dan Perluasan Kuasa Pertambangan Ekplorasi Serta Penyesuaian Menjadi Izin Usaha Pertambangan (IUP) Eksplorasi Kepada PT Mikgro Metal Perdana di Pulau Bangka, Kecamatan Likupang Timur, Kabupaten Minahasa Utara dan Surat Keputusan Bupati Minahasa Utara Nomor 152 Tahun 2012 tanggal 20 Juli 2012 tentang Perpanjangan Izin Usaha Pertambangan (IUP) Eksplorasi Kepada PT Mikgro Metal Perdana di Pulau Bangka, Kecamatan Likupang Timur, Kabupaten Minahasa Utara.

Upaya eksekusi putusan pun telah dilakukan dengan sesuai dengan ketentuan UndangUndang PTUN. Penggugat telah mengirimkan permohonan eksekusi kepada ketua pengadilan, yang kemudian di tindak lanjuti dengan dikeluarkannya Surat Ketua Pengadilan Tata Usaha Negara Manado kepada Bupati Minahasa Utara No. W4-TUN2/781/HK.06/2014 tanggal 26 Juni 2014 yang pokoknya 
memerintahkan Bupati Minahasa Utara agar melaksanakan putusan yang telah memperoleh kekuatan hukum tetap. Selanjutnya Ketua Pengadilan TUN Manado mengeluarkan Pengumuman PTUN Manado Nomor W4TUN2/891/HK.06/2014 tanggal 22 juli 2014 tentang pengumuman di media massa cetak setempat tentang Bupati Minahasa Utara tidak taat hukum.

Usaha eksekusi putusan secara hierarkis pun dilakukan dengan dikirimkannya Surat Ketua PTUN Manado ke Presiden Republik Indonesia Nomor W4-TUN2/900/HK.06/VII/2014 tanggal 24 Juli 2014 yang kemudian telah ditanggapi Presiden melalui Surat Mensesneg ke Mendagri No. $\quad$ R.116/M.Sesneg/D-4/PU.10.01/9/2014 tanggal 3 September 2014 akan tetapi tidak kunjung ditindak lanjuti. Faktanya aktifitas pertambangan bijih besi di Pulau Bangka tersebut bukannya berhenti atau dihentikan oleh pejabat yang berwenang, tetapi justru semakin intensif bahkan dikawal oleh aparat kepolisian dan TNI AD.

Rapat koordinasi 11 kementerian dan instansi terkait pada 11 juni 2014 di kantor Unit Kerja Presiden Bidang Pengawasan dan Pengendalian Pembangunan (UKP4) memutuskan untuk menghentikan sementara kegiatan pertambangan biji besi miliki PT Mikgro Metal Perdana di Pulau Bangka, namun keputusan tersebut tidak dihiraukan dan kegiatan pertambangan tetap dilaksanakan. Bahkan pada tanggal 17 Juli 2014 Menteri ESDM Jero Wacik menerbitkan IUP Operasi Produksi melalui Keputusan Menteri ESDM Nomor 31009 K/30/MEM/2014 yang meningkatkan status dari sebelumnya IUP Eksplorasi yang telah dibatalkan oleh Mahkamah Agung.

Sampai saat itu pun, Bupati Minahasa Utara masih tetap tidak mentaati Putusan Kasasi Mahkamah Agung Nomor 291 K/TUN/2013 jo Putusan Banding PTTUN Makassar Nomor 165/B.TUN/2012/PT.TUN.MKS jo. Putusan PTUN Manado Nomor 4/G.TUN/2012/PTUN.MDO untuk mencabut Surat Keputusan Bupati Minahasa Utara Nomor

https://www.google.com/amp/s/manado.antaranews.co $\mathrm{m} / \mathrm{amp} /$ berita/21490/ukp4pertambangan -biji-besi-pulaubangka-dihentikan diakses tanggal 02 Agustus 2020 Pukul 23.18 WITA.
162 Tahun 2010 tanggal 20 Juli 2010 tentang Perpanjangan dan Perluasan Kuasa Pertambangan Ekplorasi Serta Penyesuaian Menjadi Izin Usaha Pertambangan (IUP) Eksplorasi Kepada PT Mikgro Metal Perdana di Pulau Bangka, Kecamatan Likupang Timur, Kabupaten Minahasa Utara dan Surat Keputusan Bupati Minahasa Utara Nomor 152 Tahun 2012 tanggal 20 Juli 2012 tentang Perpanjangan Izin Usaha Pertambangan (IUP) Eksplorasi Kepada PT Mikgro Metal Perdana di Pulau Bangka, Kecamatan Likupang Timur, Kabupaten Minahasa Utara.

Dari fakta di atas dapat disimpulkan beberapa hal, yakni bahwa eksekusi putusan pengadilan tata usaha negara sangat lemah dalam penerapannya. Tidak adanya upaya paksa yang dimiliki oleh pengadilan TUN membuat pejabat pemerintah dapat mengabaikan putusan tersebut tanpa takut sanksi hukum yang akan dikenakan terhadapnya. Beberapa upaya paksa pun tidak dapat memaksa Bupati Minahasa Utara untuk mentaati putusan pengadilan. Upaya paksa yang hadir pun menurut penulis masih terkesan lemah dalam penerapannya. Salah satunya adalah sanksi pembayaran Dwangsom (uang paksa) yang harus dibayarkan oleh pihak yang tidak mentaati keputusan pengadilan masih tidak jelas dalam mekanisme eksekusi di lapangan, sehingga masih sukar untuk diterapkan.

\section{B. Rehabilitasi Lingkungan Pulau Bangka Pascatambang}

Setelah melewati perjalanan yang cukup panjang, perjuangan masyarakat Pulau Bangka Kecamatan Likupang Timur, Kabupaten Minahasa Utara yang menolak keberadaan tambang biji besi PT Mikgro Metal Perdana akhirnya membuahkan hasil setelah Menteri ESDM, Ignasius Jonan, mencabut Izin Usaha Pertambangan (IUP) tersebut. Pencabutan Izin Usaha Pertambangan (IUP) tersebut dituangkan dalam surat Keputusan Menteri Energi dan Sumber Daya Mineral Republik Indonesia Nomor 1361 K/30/MEM/2017 tentang Pencabutan Keputusan Menteri Energi dan Sumber Daya Mineral Nomor 3109 K/30/MEM/2014 tanggal 17 Juli 2014 tentang 
Izin Usaha Pertambangan Operasi Produksi Kepada PT Mikgro Metal Perdana. ${ }^{8}$

Namun bukan berarti masalah yang ada di Pulau Bangka telah selesai. Banyak pekerjaan rumah yang harus dihadapi terutama pemulihan atau rehabilitasi terhadap lingkungan sekitar Pulau Bangka yang akibat dari adanya kegiatan pertambangan menjadi rusak. Kerusakan yang terjadi mulai dari kerusakan terhadapa bukit, sejumlah jenis terumbu karang, serta penimbunan hutan mangrove yang dilakukan selama perusahaan beroperasi.

Untuk menentukan seberapa besar kerugian atau kerusakan lingkungan hidup yang terjadi akibat pertambangan biji besi di Pulau Bangka maka harus dilakukan audit lingkungan. ${ }^{9}$ Audit lingkungan tersebut wajib dilakukan oleh pemegang usaha/ pemegang izin usaha yang dalam hal ini adalah PT Mikgro Metal Perdana dengan pengawasan dari pemerintah (Menteri ESDM dan/atau Menteri KLHK). Jika perusahaan menolak untuk melakukan audit lingkungan maka Menteri dapat melaksanakan atau menugasi pihak ketiga yang independen untuk melaksanakan audit lingkungan hidup atas beban biaya penanggung jawab usaha dan/atau kegiatan yang bersangkutan, dan hasil audit yang dilakukan oleh auditor lingkungan itu wajib diumumkan oleh Menteri. ${ }^{10}$

Jika dalam hasil audit tersebut terdapat kerusakan terhadap lingkungan hidup dan wajib untuk dilakukan reklamasi/penanganan untuk memulihkan kembali fungsi lingkungan pasca pertambangan, maka menurut ketentuan Pasal 54 Undang-Undang 32 Tahun 2009 yang bertanggung jawab untuk melakukannya adalah penanggung jawab usaha pertambangan atau pelaku pertambangan yang dalam hal ini adalah PT Mikgro Metal Perdana. Dengan dicabutnya IUP PT Mikgro Metal Perdana oleh Menteri ESDM dalam kegiatan tambang di Pulau Bangka maka PT Mikgro Metal Perdana sebagai pelaku usaha pertambangan tetap wajib melakukan pengembalian fungsi lingkungan hidup di Pulau

\section{8}

https://m.hukumonline.com/berita/baca/It58e6137e694/ tindaklanjuti-surat-ptun-jakarta-menteri-jonan-cabut-iuppt-mmp/ diakses tanggal 02 Agustus 2020 Pukul 23.52 WITA.

9 Pasal 48-52 Undang-Undang Nomor 32 Tahun 2009 tentang Perlindungan dan Pengelolaan Lingkungan Hidup.

${ }^{10}$ Pasal 50 Undang-Undang Nomor 32 Tahun 2009
Bangka. Sesuai ketentuan Pasal 50 ayat (3) Undang-Undang Nomor 4 Tahun 2009 menyatakan Pemegang IUP, IUPK, atau IPR yang dikenai sanksi administratif berupa pencabutan IUP, IUPK, atau IPR tidak menghilangkan kewajibannya untuk melakukan reklamasi dan pascatambang.

Undang-Undang No 4 Tahun 2009 Pasal 1 angka (27) menyebutkan "Kegiatan pascatambang yang selanjutnya disebut pascatambang, adalah kegiatan terencana, sistematis, yang berlanjut setelah akhir sebagian atau seluruh kegiatan usaha pertambangan untuk memulihkan fungsi lingkungan alam dan fungsi sosial menurut kondisi lokal diseluruh wilayah penambangan". Pemulihan fungsi lingkungan hidup sebagaimana dimaksud dilakukan dengan tahapan: ${ }^{11}$
a. penghentian sumber pencemaran dan pembersihan unsur pencemar;
b. remediasi;
c. rehabilitasi;
d. restorasi; dan/atau
e. cara lain yang sesuai dengan perkembangan ilmu pengetahuan dan teknologi.

Ketentuan lebih lanjut mengenai tata cara pemulihan fungsi lingkungan hidup diatur dalam Peraturan Pemerintah No. 78 Tahun 2010 tentang Reklamasi dan Pascatambang. Pasal 2 ayat (1), (2), (3) dan (4) mengenai Prinsip Reklamasi dan Pascatambang menyatakan

(1) Pemegang Izin Usaha Pertambangan Eksplorasi (IUP) dan Izin Usaha Pertambangan Khusus (IUPK) Eksplorasi wajib melaksanakan reklamasi,

(2) Pemegang Izin Usaha Pertambangan (IUP) Operasi Produksi dan Izin Usaha Pertambangan Khusus (IUPK) Operasi Produksi wajib melaksanakan reklamasi dan pascatambang.

(3) Reklamasi sebagaimana dimaksud pada ayat (1) dilakukan terhadap lahan terganggu pada kegiatan eksplorasi dan

(4) Reklamasi dan pascatambang sebagaimana dimaksud pada ayat (2) dilakukan terhadap lahan terganggu pada kegiatan pertambangan dengan sistem dan metode: (a) penambangan

\footnotetext{
${ }^{11}$ Pasal 54 ayat (2) Undang-Undang Nomor 32 Tahun 2009
} 
terbuka; dan (b) penambangan bawah tanah

Di dalam Peraturan Pemerintah No. 78 Tahun 2010 dijelaskan juga mengenai Reklamasi dan Pascatambang yang memiliki kaitan yang erat dengan tanggung jawab perusahaan tambang. Dengan tujuan yaitu menciptakan adanya pembangunan berkelanjutan, maka dari itu kegiatan pertambangan harus tetap memperhatikan kualitas lingkungan serta prinsip-prinsip pengelolaanya serta dukungan dari masyarakat sekitar. Namun timbul pertanyaan, apakah dengan segala permasalahan yang menjerat PT Mikgro Metal Perdana dari awal proses pemberian kuasa pertambangan tahun 2008 hingga dicabutnya IUP pada tahun 2017 oleh Menteri ESDM, PT Mikgro Metal Perdana akan secara sukarela melaksanakan ketentuan peraturan perundang-undangan tentang proses reklamasi/rehabilitasi untuk memulihkan fungsi lingkungan Pulau Bangka?

Menurut penulis, ada kemungkinan PT Mikgro Metal Perdana tidak akan melaksanakan kewajibannya reklamasi/rehabilitasi untuk memulihkan fungsi lingkungan Pulau Bangka. Oleh karena itu terkait hal tersebut pemerintah wajib pro aktif dalam mengawasi pelaksanaan proses reklamasi pascatambang. Dalam ketentuan Pasal 140 Undang-Undang Nomor 4 Tahun 2009, menyatakan:

(1) Menteri melakukan pengawasan terhadap penyelenggaraan pengelolaan usaha pertambangan yang dilaksanakan oleh pemerintah provinsi dan pemerintah kabupaten kota sesuai dengan kewenangannya.

(2) Menteri dapat melimpahkan kepada gubernur untuk melakukan pengawasan terhadap penyelenggaraan kewenangan pengelolaan di bidang usaha pertambangan sebagaimana dimaksud pada ayat (1) yang dilaksanakan oleh pemerintah kabupaten/ kota.

(3) Menteri, gubernur, dan bupati/ walikota sesuai dengan kewenangannya melakukan pengawasan atas pelaksanaan kegiatan usaha pertambangan yang dilakukan oleh pemegang IUP, IPR, atau IUPK.
Pengawasan sebagairnana dimaksud dalam Pasal 140 Undang-Undang Nomor 4 Tahun 2009, antara lain berupa: ${ }^{12}$

a. teknis pertambangan;

b. pemasaran;

c. keuangan;

d. pengolahan data mineral dan batubara;

e. konservasi sumber daya mineral dan batubara;

f. keselamatan dan kesehatan kerja pertambangan;

g. keselamatan operasi pertambangan;

h. pengelolaan lingkungan hidup, reklamasi, dan pascatambang;

i. pemanfaatan barang, jasa, teknologi, dan kemampuan rekayasa dan rancang bangun dalam negeri;

j. pengembangan tenaga kerja teknis pertambangan;

k. pengembangan dan pemberdayaan masyarakat setempat;

I. penguasaan, pengembangan, dan penerapan teknologi pertambangan;

$\mathrm{m}$. kegiatan-kegiatan lain di bidang kegiatan usaha pertambangan yang menyangkut kepentingan umum;

n. pengelolaan IUP atau IUPK; dan

o. jumlah, jenis, dan mutu hasil usaha pertambangar.

Dalam ketentuan huruf ' $h$ ' di atas jelas mewajibkan pengawasan oleh Menteri, Gubernur, bupati/walikota atas pelaksanaan pengelolaan lingkungan hidup, reklamasi dan pascatambang. Peran aktif pemerintah baik pusat maupun daerah dalam reklamasi Pulau Bangka diperlukan untuk menjamin kembalinya fungsi lingkungan hidup Pulau Bangka. Meski dengan ketentuan tersebut masih tidak berjalan efektif, maka bagi PT Mikgro Metal Perdana sebagai pihak yang bertanggungjawab akan berlaku ketentuan peraturan perundangundangan yang memuat beberapa sanksi.

Dalam UU NO. 40 Tahun 2007 Tentang Perseroan Terbatas Pasal 74 ayat (1) menyatakan Perseroaan yang menjalankan kegiatan usahanya di bidang dan/atau berkaitan dengan sumber daya alam wajib melaksanakan Tanggung Jawab Sosial dan Lingkungan. Hal ini lebih di perjelas lagi dengan ayat (3), Perseroan yang tidak melaksanakan kewajiban sebagaimana dimaksud dalam ayat

${ }^{12}$ Pasal 141 ayat (1) Undang-Undang Nomor 4 Tahun 2009 
(1) dikenai sanksi sesuai dengan ketentuan peraturan perundang-undangan. Dalam Peraturan Pemerintah No. 78 Tahun 2010 yang mengatur lebih khusus tentang Reklamasi dan Pascatambang hanya memuat sanksi administratif. Sehingga menurut penulis sanksi yang ada masih terlalu ringan, sanksi pidana sebagai ultimum remedium tidak diterapkan di dalam peraturan pemerintah tersebut.

Sanksi pidana dapat diberikan kepada perusahaan pertambangan yang mengakibatkan rusaknya lingkungan hidup. Dalam UU No. 32 Tahun 2009 pada Bab 15 mengenai ketentuan pidana Pada pasal 98 (1) : setiap orang yang dengan sengaja melakukan perbuatan yang mengakibatkan dilampauinya baku mutu udara ambien, baku mutu air, baku mutu air laut atau kriteria baku kerusakan lingkungan hidup, di pidana dengan pidana penjara paling singkat 3 (tiga) tahun dan paling lama 10 (sepuluh) tahun dan denda paling sedikit Rp. 3000.000.000,00 (tiga miliar rupiah) dan paling banyak Rp. 10.000.000.000,00 (sepuluh miliar rupiah)

\section{PENUTUP}

\section{A. Kesimpulan}

1. Putusan Mahkamah Agung Nomor 291 K/TUN/2013 jo Putusan Pengadilan Tinggi Tata Usaha Negara Makassar Nomor 165/B.TUN/2012/PT.TUN.MKS jo Putusan Pengadilan Tata Usaha Negara Manado Nomor 04/G.TUN/2012/PTUN.MDO yang telah mempunyai kekuatan hukum tetap, memerintahkan Kepada Bupati Minahasa Utara untuk mencabut Surat Keputusan Bupati Minahasa Utara Nomor 162 Tahun 2010 tanggal 20 Juli 2010 tentang Perpanjangan dan Perluasan Kuasa Pertambangan Ekplorasi Serta Penyesuaian Menjadi Izin Usaha Pertambangan (IUP) Eksplorasi Kepada PT Mikgro Metal Perdana di Pulau Bangka, Kecamatan Likupang Timur, Kabupaten Minahasa Utara dan Surat Keputusan Bupati Minahasa Utara Nomor 152 Tahun 2012 tanggal 20 Juli 2012 tentang Perpanjangan Izin Usaha Pertambangan (IUP) Eksplorasi Kepada PT Mikgro Metal Perdana di Pulau Bangka, Kecamatan Likupang Timur, Kabupaten Minahasa Utara, hingga saat ini eksekusi terhadap putusan tersebut belum dilakukan. Mekanisme untuk mengusahakan dipatuhinya putusan oleh Bupati Minahasa Utara telah dilakukan oleh PTUN Manado, namun tetap tidak membuahkan hasil.

2. Dengan dikeluarkannya Surat Keputusan Menteri Energi dan Sumber Daya Mineral Republik Indonesia Nomor 1361 K/30/MEM/2017 tentang Pencabutan Keputusan Menteri Energi dan Sumber Daya Mineral Nomor 3109 K/30/MEM/2014 tanggal 17 Juli 2014 tentang Izin Usaha Pertambangan Operasi Produksi Kepada PT Mikgro Metal Perdana, menghentikan seluruh kegiatan pertambangan PT Mikgro Metal Perdana di Pulau Bangka. Sebagai pemegang Izin Usaha Pertambangan, PT Mikgro Metal Perdana diwajibkan untuk melakukan rehabilitasi/reklamasi pascatambang untuk mengembalikan fungsi lingkungan Pulau Bangka sesuai ketentuan peraturan perundangundangan nasional.

\section{B. Saran}

1. Agar Bupati Minahasa Utara menaati Putusan Mahkamah Agung Nomor 291 K/TUN/2013 jo Putusan Pengadilan Tinggi Tata Usaha Negara Makassar Nomor 165/B.TUN/2012/PT.TUN.MKS jo Putusan Pengadilan Tata Usaha Negara Manado Nomor 04/G.TUN/2012/PTUN.MDO yang telah mempunyai kekuatan hukum tetap, karena sebagai seorang Bupati, seharusnya memberi contoh, teladan, dan itikad baik untuk menaati hukum yang berlaku di Indonesia.

2. Agar Menteri ESDM, gubernur, bupati/walikota khususnya dan jajaran pemerintahan pada umumnya untuk lebih hati-hati dalam mengeluarkan keputusan yang memiliki akibat terhadap kehidupan masyarakat. Terutama yang berkaitan dengan hajat hidup dan lingkungan hidup masyarakat.

3. Agar PT Mikro Metal Perdana bisa bertanggungjawab atas kerusakan lingkungan Pulau Bangka dan bersedia untuk mengembalikan fungsi lingkungan pulau Bangka melalui kegiatan 
rehabilitasi, reklamasi pascatambang dengan memperhatikan kepentingan masyarakat sekitar.

\section{DAFTAR PUSTAKA}

Buku

Fatkhurohman, dkk., 2004, Memahami Keberadaan Mahkamah Konstitusi Di Indonesia, Citra Aditya Bakti, Bandung.

Ishaq, H. 2017. Metode Penelitian Hukum \& Penulisan Skripsi, Tesis dan Disertasi. Alfabeta. Bandung.

Soekanto, Soerjono \& Mamudji, Sri. 2001. Penelitian Hukum Normatif Suatu Tinjauan Singkat. Rajawali Pers. Jakarta.

Soerjono Soekanto. 1986. Pengantar Penelitian Hukum. Jakarta. UI-Press.

Mamudji, Sri et al. 2005. Metode Penelitian dan Penulisan Hukum. Badan Penerbit Fakultas Hukum Universitas Indonesia. Jakarta.

Marzuki, Peter Mahmud. 2017. Penelitian Hukum Edisi Revisi. Kencana. Jakarta.

Sugono, Dendy. dkk. 2011. Kamus Besar Bahasa Indonesia Pusat Bahasa Edisi Keempat Departemen Pendidikan Nasional. Gramedia Pustaka Utama. Jakarta.

SF. Marbun. 2011. Peradilan Administrasi Negara dan Upaya Administrasi di Indonesia. FH UII Press. Yogyakarta.

Nandang Alamsah Deliarnoor, dkk. 2017. Teori \& Praktek Kewenangan. Pandiva Buku. Yogyakarta.

Ridwan HR. 2014. Hukum Administrasi Negara. Rajawali Pers. Jakarta.

Indroharto. 1993. Usaha Memahami UndangUndang tentang Peradilan Tata Usaha Negara. Pustaka Sinar Harapan. Jakarta.

Philipus M. Hadjon. 2002. Pengantar Hukum Administrasi Indonesia. Gadjah Mada University Press. Yogyakarta.

Jimly Asshiddiqie. 2010. Perihal UndangUndang. Rajawali Pers. Jakarta.

HR, Ridwan. 2016, Hukum Administrasi Negara Edisi Revisi, Raja Grafindo Persada, Jakarta.

Setiadi, Wicipto. 1995, Hukum Acara Pengadilan Tata Usaha Negara Suatu Perbandingan, Raja Grafindo Persada, Jakarta.
T, Titik Triwulan. dan Widodo, Ismu Gunadi. 2010, Hukum Tata Usaha Negara dan Hukum Acara Tata Usaha Negara Indonesia, Kencana, Surabaya.

M, Ali Abdullah. 2014, Teori dan Praktek Hukum Acara Peradilan Tata Usaha Negara Pasca-Amandemen, Prenada Media Group, Jakarta.

Zairin Harahap, 2014, Hukum Acara Peradilan Tata Usaha Negara, Rajagrafindo Persada, Yogyakarta.

\section{Peraturan Perundang-Undangan}

Undang-Undang Dasar Negara Republik Indonesia Tahun 1945

Undang-Undang Nomor 30 Tahun 2014 tentang Administrasi Pemerintahan

Undang-Undang Nomor 14 Tahun 1970 tentang Ketentuan-Ketentuan Pokok Kekuasaan Kehakiman

Undang-Undang No. 4 Tahun 2004 tentang Pokok-pokok Kekuasaan Kehakiman

Undang-Undang Nomor 5 Tahun 1986 tentang Peradilan Tata Usaha Negara

Undang-Undang Nomor 9 Tahun 2004 tentang Perubahan atas Undang-Undang Nomor 5 Tahun 1986 tentang Peradilan Tata Usaha Negara

Undang-Undang Nomor 51 Tahun 2009 tentang Perubahan Kedua atas Undang-Undang Nomor 5 Tahun 1986 tentang Peradilan Tata Usaha Negara

Undang-Undang Nomor 4 Tahun 2009 tentang Pertambangan Mineral dan Batubara

Undang-Undang Nomor 32 Tahun 2009 tentang Perlindungan dan Pengelolaan Lingkungan Hidup.

Peraturan Pemerintah Republik Indonesia Nomor 7 Tahun 1991 Tentang Penerapan Undang-Undang Nomor 5 Tahun 1986 Tentang Pengadilan Tata Usaha Negara

Peraturan Pemerintah Nomor 23 Tahun 2010 tentang Pelaksanaan Kegiatan Usaha Pertambangan Mineral dan Batubara

Peraturan Pemerintah Nomor 78 Tahun 2010 tentang Reklamasi Paska Tambang

\section{Internet}

http://iyan88simple.blogspot.co.id/2012/09/pe laksanaan-putusan-pengadilan- 
tata.html diakses Pada Tanggal 30 Juli 2020 Pukul 15.45 WITA.

http://www.hukumonline.com/klinik/detail/lt5 206db0fe239e/masalah-eksekusipaksa-putusan -ptun diakses Pada tanggal 30 Juli 2020 Pukul 16.50 WITA.

https://id.m.wikipedia.org/wiki/Pulau_Bangka, _Sulawesi_Utara diakses Tanggal 01 Juli 2020 Pukul 20.50 WITA

http://www.ppk-kp3k.kkp.go.id/direktoripulau/index.php/public_c/pulau_info/6 578 diakses Tanggal 01 Juli 2020 Pukul 20.26 WITA.

https://raypratama.blogspot.com/2015/04/eks ekusi-putusan-pengadilan-tatausaha.html? $\mathrm{m}=1$ diakses tanggal 31 agustus 2020 Pukul 21.25 WITA.

https://www.google.com/amp/s/manado.antar anews.com/amp/berita/21490/ukp4pe rtambangan -biji-besi-pulau-bangkadihentikan diakses tanggal 02 Agustus 2020 Pukul 23.18 WITA.

https://m.hukumonline.com/berita/baca/lt58e 6137e694/tindaklanjuti-surat-ptunjakarta-menteri-jonan-cabut-iup-pt$\mathrm{mmp} /$ diakses tanggal 02 Agustus 2020 Pukul 23.52 WITA.

Undang-Undang Nomor 32 Tahun 2009 tentang Perlindungan dan Pengelolaan Lingkungan Hidup. 